\title{
Design Research: Mengembangkan Kemampuan Penalaran Induktif dengan Model-Eliciting Activities pada Pembelajaran Remedial Pola Bilangan untuk Kelas VIII E SMP Negeri 22 Jakarta
}

\author{
Fitri Khairunnisa $^{1, a)}$, Wardani $\operatorname{Rahayu}^{2, \text { b) }}{ }^{\text {, Meiliasari }}{ }^{3, c)}$ \\ ${ }^{1,2,3}$ Universitas Negeri Jakarta \\ Email: ${ }^{\text {a) }}$ itrikhairunnisa_3115153042@ $\mathrm{mhs} . u n j . a c . i d,{ }^{b}$ wardani9164@ gmail.com, ${ }^{\mathrm{c}}$ meiliasari@unj.ac.id
}

\begin{abstract}
Abstrak
Penelitian-penelitian terdahulu menunjukkan bahwa peserta didik kelas VIII mengalami kesulitan dalam menentukan output suatu pola bilangan apabila diberikan input yang besar dan menentukan rumus umum $\mathrm{U}_{n}$. Hal serupa juga terjadi pada siswa kelas VIII SMP Negeri 22 Jakarta. Sebanyak lebih dari 50\% peserta didik kelas VIII E SMP Negeri 22 Jakarta mendapat hasil Penilaian Harian (PH) di bawah Kriteria Ketuntasan Minimal (KKM). Menentukan rumus umum $\mathrm{U}_{n}$ adalah kesulitan yang paling sering dijumpai oleh peserta didik. Menentukan rumus umum $\mathrm{U}_{n}$ merupakan salah satu indikator kemampuan penalaran induktif. Berdasarkan hasil PH tersebut, kemampuan penalaran induktif peserta didik kelas VIII E SMP Negeri 22 Jakarta masih lemah. Oleh karena itu, dirancanglah teori pembelajaran lokal dalam pembelajaran remedial pada pokok bahasan Pola Bilangan dengan menggunakan Model-Eliciting Activities (MEAs) untuk mengembangkan kemampuan penalaran induktif peserta didik kelas VIII E SMP Negeri 22 Jakarta. Metodologi penelitian yang digunakan adalah design research, yang dimulai dari preliminary design, teaching experiment, dan retrospective analysis. Hasil penelitian menunjukkan bahwa MEAs dapat mengembangkan kemampuan penalaran induktif peserta didik dalam pembelajaran remedial pada pokok bahasan Pola Bilangan.
\end{abstract}

Kata kunci: penalaran induktif, model-eliciting activities (MEAs), remedial, pola bilangan.

\section{PENDAHULUAN}

Pola merupakan topik paling fundamental karena menuntun beberapa konsep dasar dalam matematika. Hal ini sesuai dengan pernyataan The Australian Association of Mathematics Teachers (AAMT) bahwa pola menuntun beberapa konsep dasar, seperti konsep perkalian, bilangan genap, dan bilangan ganjil yang muncul dari pola berulang; bentuk aljabar sebagai salah satu representasi dari pola berkembang; serta eksplorasi pola ruang atau spasial yang mengarahkan pada konsep simetri, kesebangunan, kolinearitas, sifat bangun-bangun datar, dan konsep geometri lainnya. Selain AAMT, Kementerian Pendidikan dan Kebudayaan (Kemendikbud) juga menyebutkan bahwa mengidentifikasi dan menggunakan pola untuk membuat prediksi dan aturan umum merupakan salah satu kompetensi yang harus dicapai oleh peserta didik pada tingkat sekolah menengah pertama

Pola dalam matematika dibedakan menjadi dua, yaitu pola berulang dan pola berkembang. Pola berulang merupakan pola yang akan terus-menerus diulang sehingga memiliki unit pengulangan sedangkan pola berkembang merupakan pola yang didasarkan pada perubahan konstan (Taylor-Cox, 2005). Perubahan ini dapat berupa peningkatan atau penurunan.

Adanya perubahan konstan berupa peningkatan atau penurunan seringkali menyebabkan peserta didik kesulitan dalam menyelesaikan permasalahan pola berkembang karena lebih rumit daripada pola berulang yang hanya terus-menerus diulang. Hasil survei TIMSS 2011 menunjukkan bahwa peserta 
didik kelas VIII SMP di Indonesia masih sangat lemah dalam menentukan suku ke-100 dari suatu pola berkembang. Hanya $12 \%$ peserta didik kelas VIII Indonesia yang mampu menyelesaikan permasalahan tersebut. Penelitian yang dilakukan oleh Wildani juga menunjukkan bahwa peserta didik kesulitan menemukan suku ke-100 dari suatu susunan konfigurasi objek. Selain menentukan suku ke-100, peserta didik juga kesulitan dalam menentukan rumus umum $\mathrm{U}_{n}$ (Wildani, 2018). Hal serupa juga ditemukan di SMP Negeri 22 Jakarta. Hasil Penilaian Harian $(\mathrm{PH})$ pada pokok bahasan Pola Bilangan menunjukkan bahwa lebih dari 50\% peserta didik tidak mencapai KKM dan kesulitan yang paling banyak dialami adalah menentukan rumus umum $\mathrm{U}_{n}$.

Maulana (2017) menyebutkan bahwa menemukan pola, menggunakan pola hubungan untuk menganalisis situasi matematis, dan membuat generalisasi berupa rumus umum termasuk ke dalam penalaran induktif. Penalaran induktif adalah kegiatan berpikir yang disertai dengan penarikan kesimpulan berdasarkan data observasi terbatas (Maulana, 2017). Serupa dengan pendapat Maulana, Sumarmo (2017) memiliki pandangan bahwa penalaran induktif adalah kegiatan penarikan kesimpulan berdasarkan data-data yang teramati. Berdasarkan hasil survei TIMSS 2011, penelitian Wildani, dan hasil kunjungan ke SMP Negeri 22 Jakarta, masih banyak peserta didik kelas VIII yang lemah dalam bernalar induktif.

Berdasarkan pengamatan yang telah dilakukan saat mengunjungi SMP Negeri 22 Jakarta, pada pembelajaran Pola Bilangan, guru memberikan trik kepada peserta didik bagaimana langkah-langkah menentukan rumus umum $\mathrm{U}_{n}$. Setelah memberitahukan langkah-langkah tersebut, guru menuliskan contoh soal dan memberikan latihan yang tidak jauh berbeda. Hal ini menyebabkan peserta didik akan mengalami kesulitan jika tidak menghafal langkah-langkah dalam menentukan rumus umum $\mathrm{U}_{n}$ tersebut karena tidak memahami konsep dalam menemukan pola. Selain itu, peserta didik juga akan kesulitan jika diberikan soal yang berbeda dengan contoh dari guru.

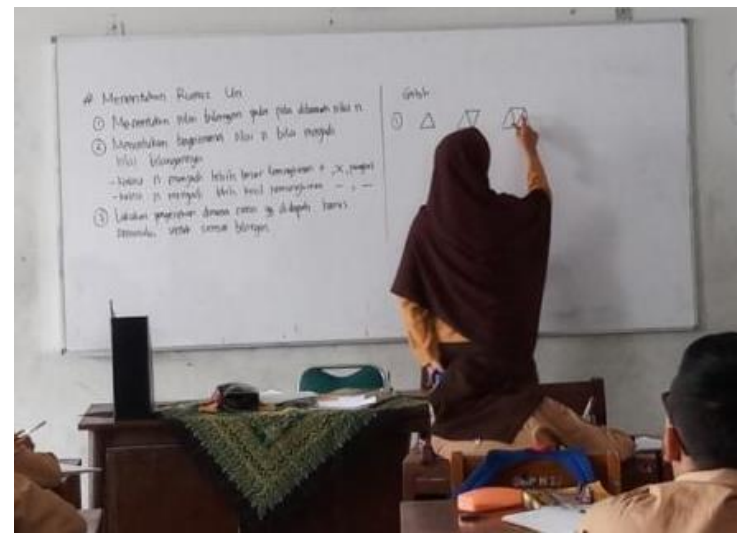

GAMBAR 1. Guru Memberitahukan Langkah-Langkah Menentukan Rumus Umum $\mathrm{U}_{n}$

Berdasarkan permasalahan di atas, diperlukan program remedial dengan pendekatan pembelajaran yang berbeda. Pendekatan pembelajaran yang berbeda dapat memberikan pengalaman baru bagi peserta didik saat mempelajari pola bilangan, terlebih jika pendekatan pembelajaran tersebut menggunakan konteks kehidupan nyata. Jika guru hanya menuliskan sekumpulan objek atau barisan bilangan, peserta didik akan berpikir bahwa pola bilangan merupakan materi yang abstrak karena hanya berisi rumus-rumus dan angka-angka. Salah satu pendekatan pembelajaran yang menggunakan konteks kehidupan nyata adalah Model-Eliciting Activities (MEAs).

MEAs dibuat atas tanggapan kebutuhan para peneliti, guru, dan pemangku kepentingan pendidikan lainnya untuk melakukan analisis terhadap pemikiran peserta didik saat memecahkan permasalahan. Chamberlin (2002) menyatakan bahwa MEAs merupakan pendekatan pembelajaran yang berisi kegiatan-kegiatan matematis untuk menghasilkan model.

MEAs terdiri atas 4 komponen, yaitu membaca artikel (reading passage), menjawab pertanyaan persiapan (readiness question), membaca deskripsi permasalahan yang disajikan (data section), dan menyelesaikan permasalahan (problem solving task) (Chamberlin \& Moon, 2005). Tujuan komponen reading passage adalah untuk membangkitkan minat peserta didik dan diskusi mengenai konteks 
masalah pada artikel. Readiness question memuat pertanyaan-pertanyaan sederhana, bersifat inferensi, atau terkait interpretasi data dengan tujuan peserta didik memiliki pengetahuan dasar mengenai konteks permasalahan yang ada pada artikel. Data section merupakan komponen di mana peserta didik membaca data informasi berupa gambar, diagram, bagan, tabel, atau yang lainnya dan berguna untuk menjawab problem solving task. Problem solving task memuat pertanyaanpertanyaan permasalahan yang harus dipecahkan sehingga kemampuan penalaran induktif peserta didik dapat berkembang. Selain memiliki empat komponen, MEAs juga dirancang berdasarkan enam prinsip, yaitu model construction principle, reality principle, the self-assessment principle, the construct documentation model principle, the construct shareability and reusability principle, dan the effective prototype principle (Lesh, Hoover, Hole, Kelly, \& Post, 2000).

Beberapa penelitian terdahulu menunjukkan bahwa MEAs berperan dalam membantu peserta didik dalam mengembangkan atau meningkatkan suatu kemampuan matematis. Penelitian design research yang dilakukan oleh Rahmawati, Darmawijoyo, dan Hapizah (2018) menunjukkan bahwa MEAs dapat membantu peserta didik mengembangkan kemampuan pemahaman konsep mengenai fungsi linear. Penelitian yang dilakukan oleh Putri, Afgani, dan Agustiani (2020) menunjukkan bahwa MEAs memberikan pengaruh dalam meningkatkan kemampuan penalaran generalisasi matematis peserta didik pada materi Sistem Persamaan Linear Tiga Variabel (SPLTV).

Fungsi linear memuat bentuk aljabar, sama seperti rumus umum $\mathrm{U}_{n}$ dalam pola bilangan. Generalisasi merupakan salah satu kegiatan bernalar induktif. Berdasarkan kedua penelitian yang telah disebutkan di atas, dilakukanlah penelitian ini untuk menjawab pertanyaan bagaimana kemampuan penalaran induktif peserta didik kelas VIII E SMP Negeri 22 Jakarta dapat dikembangkan pada pembelajaran remedial pola bilangan dengan menggunakan MEAs.

\section{METODE}

Penelitian ini merupakan penelitian design research. Gravemeijer (2004) menyatakan bahwa design research terdiri atas tiga tahapan, yaitu preliminary design (desain pendahuluan), teaching experiment (percobaan desain), dan retrospective analysis (analisis retrospektif). Pada tahap preliminary design, dilakukan pengamatan serta perancangan teori instruksional lokal dan Hipotesis Lintasan Belajar (HLB). Gravemeijer dan van Eerde (2009) menyatakan bahwa teori instruksional lokal adalah teori mengenai rangkaian kegiatan pembelajaran yang diterapkan untuk suatu topik tertentu beserta perangkat yang mendukung berjalannya kegiatan tersebut sedangkan HLB yaitu dugaan mengenai bagaimana cara berpikir peserta didik dapat berkembang dalam suatu kegiatan pembelajaran (Prahmana, 2017). HLB yang telah dibuat digunakan sebagai panduan dalam melaksanakan program remedial dan diujicobakan relevansinya di kelas pada tahap teaching experiment. Setelah mengujicobakannya, dilakukan perbandingan antara HLB yang telah dibuat dengan keadaan sesungguhnya di kelas lalu dibuatlah analisis data pada tahap retrospective analysis.

Penelitian ini dilaksanakan di kelas VIII E SMP Negeri 22 Jakarta dan diikuti oleh 18 peserta didik. Penelitian ini dilaksanakan pada bulan Februari 2020. Metode pengumpulan data yang digunakan dalam penelitian ini adalah observasi serta dokumen dan catatan tertulis. Catatan tertulis guru kelas mengenai perolehan hasil PH pada pokok bahasan Pola Bilangan digunakan untuk mengetahui bahwa VIII E merupakan kelas dengan nilai dan rata-rata terendah. Data yang dikumpulkan dari berbagai dokumen dapat berupa buku-buku dan jurnal-jurnal yang digunakan untuk menyusun teori instruksional lokal, HLB, serta tes awal dan tes akhir.

Tes awal dilakukan untuk mengukur kemampuan penalaran induktif peserta didik pada materi pola bilangan sebelum program remedial dilaksanakan. Tes awal dilakukan kepada 18 peserta didik. Kedelapan belas peserta didik ini merupakan rekomendasi dari guru karena masih memiliki kemampuan penalaran induktif yang lemah. Berdasarkan hasil tes awal, kedelapan belas peserta didik tersebut lalu dibagi menjadi tiga kelompok, yaitu kelompok atas, kelompok menengah, dan kelompok bawah. Setiap kelompok terdapat dua subjek penelitian sehingga total subjek ada 6 peserta didik. Pemilihan ini dilakukan untuk meminimalisasi kemungkinan peserta didik berhalangan hadir jika hanya dipilih 1 orang peserta didik dari setiap kelompok. 
Metode yang digunakan untuk menganalisis data-data penelitian adalah metode induktif. Metode induktif sering digunakan pada penelitian kualitatif karena pengumpulan dan analisis data dilakukan secara bersamaan (Ary, Jacobs, Sorensen, \& Razavieh, 2010). Metode ini dipilih karena design research memiliki batasan yang tidak tetap. Gravemeijer dan Eerde (2009) menyebutkan batasan yang tidak tetap tersebut adalah pada tahapan teaching experiment dan retrospective analysis. Retrospective analysis dapat dimulai selama teaching experiment sehingga tidak perlu menunggu sampai tahapan teaching experiment selesai untuk memperoleh semua data baru kemudian melakukan analisis. Ary, Jacobs, Sorensen, dan Razavieh (2010) menyatakan bahwa metode analisis data induktif terdiri atas tiga tahapan, yaitu familiarizing and organizing (memahami dan mengatur data), coding and reducing (melakukan koding dan mereduksi data), serta interpreting and representing (menginterpretasi dan merepresentasikan data).

\section{HASIL DAN PEMBAHASAN}

\section{Pertemuan Pertama}

Pertemuan pertama termasuk ke dalam pembelajaran tahap 1, yaitu menentukan persamaan dari suatu barisan bilangan. Konteks yang digunakan pada pertemuan pertama adalah kerajinan tangan rak dinding dari stik es krim. Penggunaan konteks permasalahan yang didasarkan pada kehidupan nyata ini sesuai dengan reality principle pada MEAs. Permasalahan yang diberikan pada pertemuan pertama adalah seseorang akan membuat rak dinding dengan memanfaatkan stik es krim. Peserta didik kemudian menentukan berapa banyak stik es krim yang diperlukan untuk membuat rak satu susun, dua susun, tiga susun, hingga empat susun jika rak dinding tersebut memuat 25 lapis stik es krim, lalu menuliskannya ke dalam bentuk barisan bilangan. Peserta didik kemudian membuat model, yaitu berupa rumus umum $\mathrm{U}_{n}$ untuk menyatakan banyak stik es krim tersebut untuk rak $n$ susun.
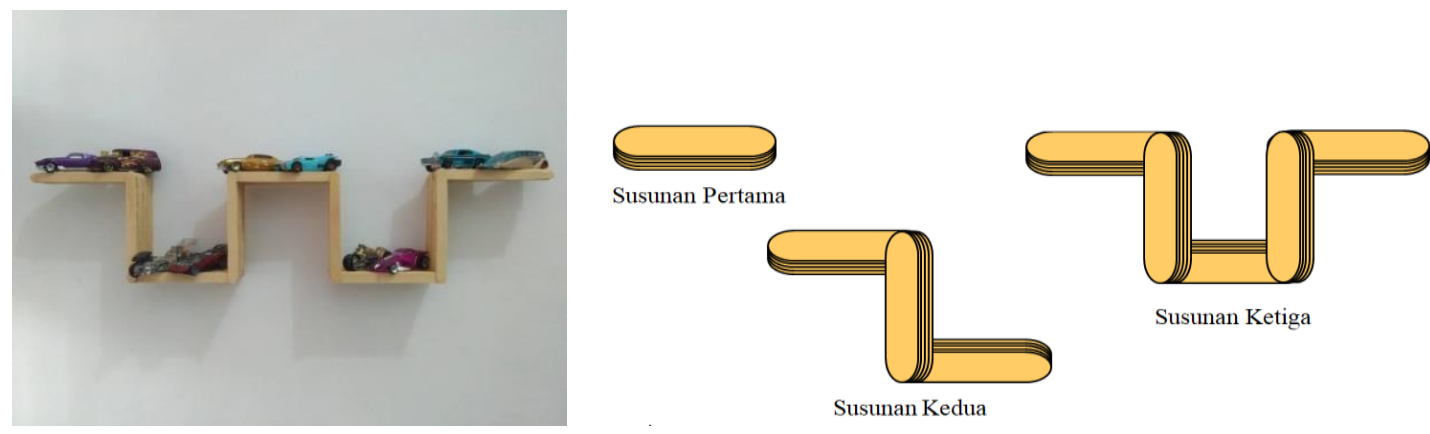

GAMBAR 2. Rak Dinding Melayang (Floating Shelf) dan Ilustrasi Susunan Rak per Susunnya

Selama peserta didik berdiskusi, guru hanya sebagai fasilitator. Guru menilai proses peserta didik dalam menghasilkan rumus umum $\mathrm{U}_{n}$, bukan berfokus pada menanyakan langsung apa rumus umumnya. Peserta didik perlu memberikan penjelasan kepada guru dan teman-teman sekelompoknya bagaimana proses mendapatkan rumus umum tersebut. Rumus umum $\mathrm{U}_{n}$ yang dihasilkan dari strategi masing-masing kelompok memenuhi model construction principle dan the construct documentation model principle pada MEAs sedangkan kegiatan diskusi di mana peserta didik membagikan hasil pemikirannya dalam memperoleh rumus umum $\mathrm{U}_{n}$ sesuai dengan the construct shareability and reusability principle pada MEAs.

Saat peserta didik membagikan proses memperoleh rumus $\mathrm{U}_{n}$ melalui diskusi, peserta didik lainnya akan menyetujui, tidak menyetujui, atau meluruskan jika terdapat kekeliruan. Peserta didik yang memberitahu kekeliruan yang dilakukan peserta didik lainnya memenuhi the self-assessment principle pada MEAs. Jika terdapat peserta didik dengan strategi yang lebih mudah dalam menentukan rumus $\mathrm{U}_{n}$ sehingga disetujui oleh peserta didik lainnya, kegiatan ini sesuai dengan the effective prototype principle pada MEAs. Oleh karena itu, rangkaian kegiatan pembelajaran menentukan banyak stik es krim yang dilalui pada pertemuan pertama ini memenuhi seluruh prinsip pada MEAs. 


\section{Pertemuan Kedua}

Pertemuan kedua masih termasuk ke dalam pembelajaran tahap 1, yaitu menentukan persamaan dari suatu barisan bilangan. Perbedaannya adalah jika pada pertemuan pertama memperkenalkan pola meningkat, pertemuan kedua mempelajari tentang pola menurun. Konteks pola menurun dalam penelitian ini adalah persediaan stok bahan baku yang akan diolah menjadi makanan. Oleh karena itu, pertemuan kedua menggunakan konteks persediaan stok beras ketan sebagai bahan baku kerak telor.

Permasalahan yang ditampilkan adalah Bu Lastri, seorang Ibu Rumah Tangga (IRT) ingin membuat sendiri kerak telor di rumah karena keberadaannya yang langka hanya pada event tertentu di Jakarta. Bu Lastri mencari berbagai referensi resep kerak telor di internet lalu merangkumnya menjadi sebuah resep yang dibuatnya sendiri. Peserta didik menentukan berapa banyak beras ketan yang masih tersisa untuk membuat 1 porsi, 2 porsi, 3 porsi, hingga 4 porsi kerak telor jika persediaan awal stok beras ketan Bu Lastri adalah 200 gram. Pertanyaan problem solving task kemudian semakin meningkat, yaitu jika stok awal beras ketan Bu Lastri adalah 2 kilogram, berapa banyak beras ketan yang masih tersisa setelah Bu Lastri selesai membuat pesanan 50 porsi kerak telor. Problem solving task terakhir yaitu peserta didik menentukan rumus umum $\mathrm{U}_{n}$ dengan memperhatikan bahwa stok awalnya adalah 2 kilogram dan selisih banyak beras ketan yang digunakan antarporsi kerak telor yaitu 25 gram.

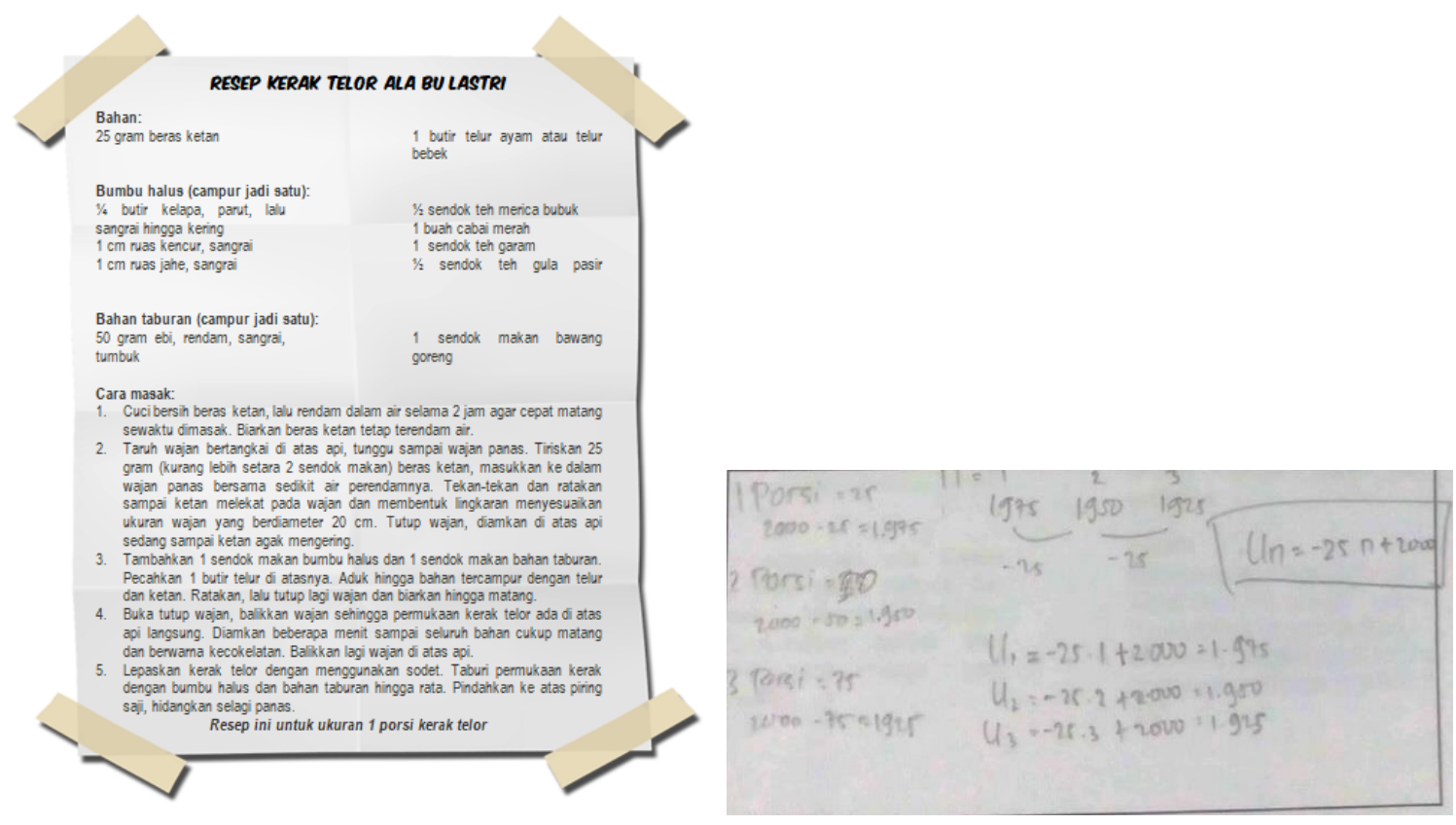

GAMBAR 2. Resep Kerak Telor Buatan Bu Lastri dan Rumus $\mathrm{U}_{n}$ yang Dihasilkan Peserta Didik

Sama dengan pertemuan sebelumnya, pertemuan kedua menggunakan konteks kehidupan nyata. Penggunaan konteks permasalahan berdasarkan real world problem memenuhi reality principle pada MEAs. Kegiatan menghasilkan model berupa rumus umum $\mathrm{U}_{n}$ untuk menyatakan sisa stok beras ketan sesuai dengan model construction principle. Ketika peserta didik memberitahukan kepada peserta didik lainnya dan menuliskan rumus umum tersebut pada Lembar Kegiatan Peserta Didik (LKPD), kegiatan pembelajaran telah memenuhi prinsip MEAs the construct documentation model principle dan the construct shareability and reusability principle.

Saat peserta didik menanyakan hal-hal yang tidak dipahaminya kepada guru, guru hanya memberikan beberapa pertanyaan pengarahan. Hal ini dilakukan agar peserta didik mampu mengetahui sendiri letak kekeliruannya dan untuk mengetahui sudah sejauh mana pemahaman peserta didik mengenai permasalahan yang ada pada LKPD. Ketika peserta didik dapat mengetahui sendiri letak kekeliruannya, di sinilah letak the self-assesment principle pada MEAs bekerja. Selain itu, kegiatan diskusi antara peserta didik dari suatu kelompok dalam mengungkapkan strateginya dapat memengaruhi kelompok belajar lainnya karena dianggap lebih mudah dalam menyelesaikan 
permasalahan. Prinsip pada MEAs yang terpenuhi pada kegiatan diskusi ini adalah the effective prototype principle.

\section{Pertemuan Ketiga}

Jika pertemuan pertama dan pertemuan kedua masih termasuk ke dalam pembelajaran tahap 1, pertemuan ketiga merupakan tahap 2, yaitu menentukan persamaan dari konfigurasi objek. Konteks yang digunakan pada pertemuan ketiga adalah pola dasar penyusunan paving block. Konteks ini dekat dengan kehidupan peserta didik karena permukaan tanah halaman SMP Negeri 22 Jakarta dipasang paving block. Pertemuan ketiga menampilkan permasalahan Pak Jaja yang memesan paving block berukuran custom dan memilih mengadopsi paving block berbentuk persegi dan persegi panjang menggunakan pola windmill.
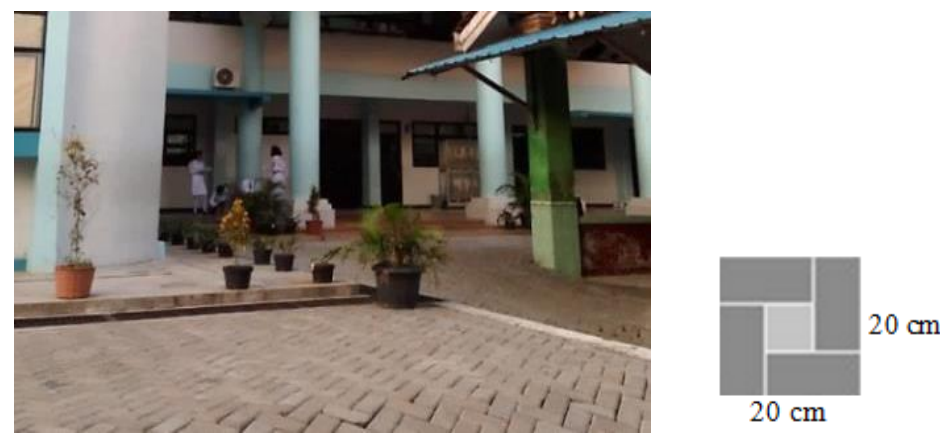

GAMBAR 3. Halaman SMP Negeri 22 Jakarta dan Pola Windmill yang Dipilih Pak Jaja

Berdasarkan pola windmill yang dipilih oleh Pak Jaja, peserta didik menentukan gambar susunan paving block berbentuk persegi dan persegi panjang yang akan dipasang pada permukaan tanah berukuran 1 meter $\times 1$ meter dan 2 meter $\times 2$ meter lalu menghitung berapa banyak paving block berbentuk persegi dan persegi panjang yang dibutuhkan untuk menutupi kedua permukaan tanah tersebut. Peserta didik kemudian menentukan rumus umum untuk mengetahui banyak paving block persegi dan persegi panjang yang dibutuhkan pada permukaan tanah berukuran $n$ meter $\times n$ meter.
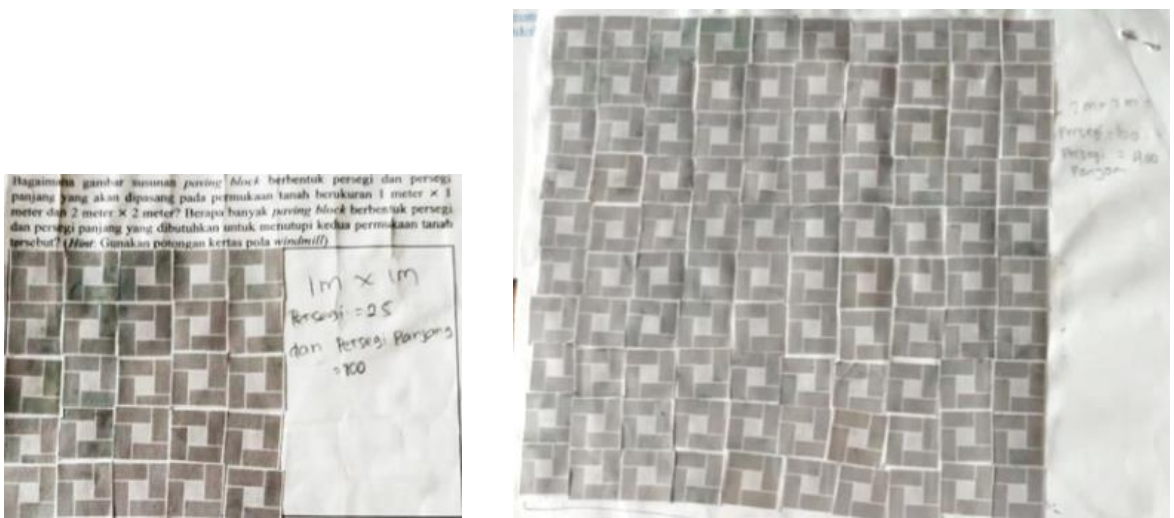

GAMBAR 4. Susunan Paving Block pada Permukaan Tanah Berukuran 1 meter $\times 1$ meter dan 2 meter $\times 2$ meter

Pemanfaatan konteks paving block yang dekat dengan kehidupan peserta didik memenuhi reality principle pada MEAs. Prinsip MEAs lainnya yang terpenuhi adalah model construction principle, ketika peserta didik menentukan banyak paving block berbentuk persegi dan persegi panjang yang dibutuhkan pada permukaan tanah berukuran $n$ meter $\times n$ meter. Penjelasan peserta didik, baik tertulis maupun lisan mengenai strategi yang dipilihnya dalam menentukan banyak paving block berbentuk persegi dan persegi panjang pada permukaan tanah berukuran $n$ meter $\times n$ meter juga sesuai dengan the construct documentation model principle pada MEAs. 
Saat mengerjakan LKPD, beberapa peserta didik mengalami kekeliruan. Salah satu kekeliruan yang dilakukan peserta didik yaitu dalam menentukan gambar susunan paving block berbentuk persegi dan persegi panjang yang akan dipasang pada permukaan tanah berukuran 1 meter $\times 1$ meter. Namun, peserta didik lainnya yang ikut berdiskusi pun memberitahukan kekeliruan itu sehingga kegiatan ini memenuhi prinsip MEAs the self-assesment principle. The construct shareability and reusability principle juga terpenuhi karena dalam menentukan banyak paving block berbentuk persegi dan persegi panjang pada permukaan tanah berukuran $n$ meter $\times n$ meter, peserta didik menjawab dengan strategi yang bervariasi. Variasi strategi yang dipilih oleh peserta didik dalam menentukan banyak paving block berbentuk persegi dan persegi panjang pada permukaan tanah berukuran $n$ meter $\times n$ meter adalah rumus cepat substitusi dan melihat pola.

Rumus cepat substitusi telah diajarkan oleh guru kelas saat pembelajaran pola bilangan bertingkat dua. Rumus tersebut diberikan sebagai trik dan peserta didik menyebutnya sebagai rumus $a b c$ karena perlu menentukan nilai $a, b$, dan $c$ yang tepat dalam perhitungannya agar bisa menghasilkan rumus $\mathrm{U}_{n}$ yang benar. Namun, beberapa peserta didik lupa trik ini. Guru pun mengajukan beberapa pertanyaan untuk menuntun peserta didik membuat rumus umum $\mathrm{U}_{n}$ dengan melihat penambahan antara pola gambar susunan pada permukaan tanah berukuran 1 meter $\times 1$ meter dengan 2 meter $\times 2$ meter. Pemilihan variasi strategi ini mengubah mindset beberapa peserta didik karena dianggap lebih mudah dan tidak perlu menghafal perhitungan $a, b$, dan $c$. Hal ini sejalan dengan the effective prototype principle pada MEAs.
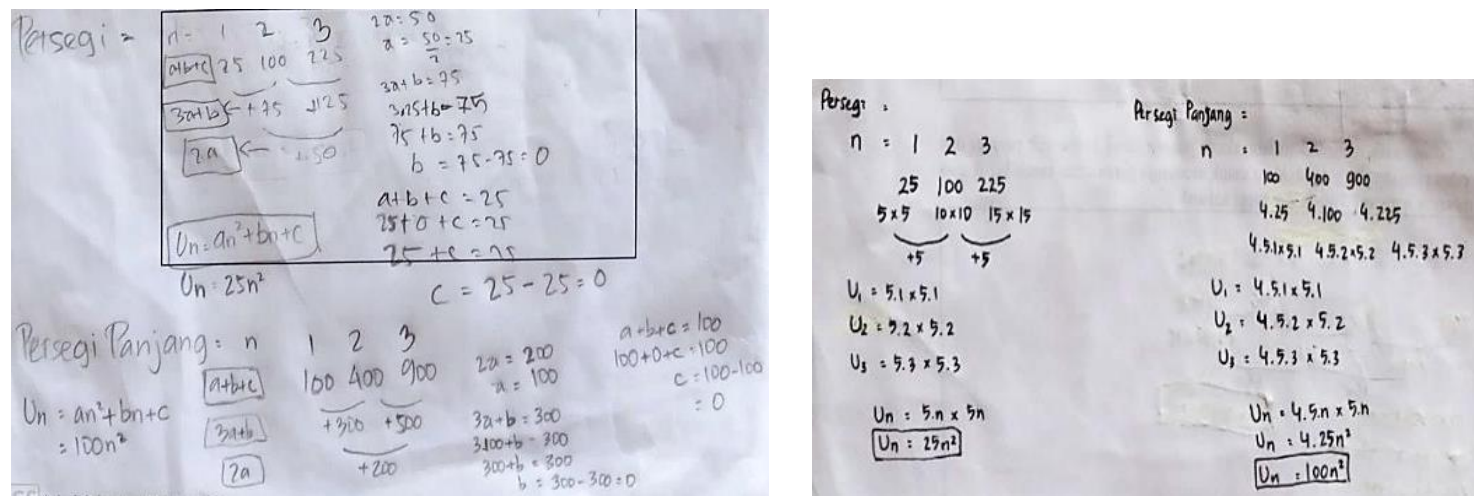

GAMBAR 5. Strategi Rumus Cepat Substitusi $a b c$ dengan Melihat Penambahan Pola

\section{PENUTUP}

\section{Kesimpulan}

Berdasarkan Pendahuluan yang telah dijabarkan, penelitian ini dilakukan untuk menjawab pertanyaan bagaimana kemampuan penalaran induktif peserta didik kelas VIII E SMP Negeri 22 Jakarta dapat dikembangkan pada pembelajaran remedial pola bilangan dengan menggunakan MEAs. Oleh karena itu, berdasarkan Hasil dan Pembahasan di atas, penelitian yang mengimplementasikan program remedial dengan MEAs ini dapat mengembangkan kemampuan penalaran induktif peserta didik kelas VIII E SMP Negeri 22 Jakarta. Selain itu, prinsip-prinsip MEAs yang telah disebutkan juga memiliki keterkaitan dalam perkembangan penalaran induktif peserta didik kelas VIII E SMP Negeri 22 Jakarta. Strategi melihat penambahan pola juga memberikan dampak yang positif karena peserta didik memahami konsep polanya, tidak hanya menghafal trik.

\section{Saran}

Meskipun penelitian ini berhasil menjawab pertanyaan bagaimana kemampuan penalaran induktif peserta didik kelas VIII SMP Negeri 22 Jakarta, tetapi dalam pelaksanaannya, diperlukan beberapa saran yang membangun demi terlaksananya penelitian di masa depan yang lebih baik. Berikut saransaran yang berkaitan dengan penelitian ini. 
1. Diperlukan pengetahuan dan referensi desain pembelajaran yang lebih luas, agar dapat merancang desain pembelajaran dan Hipotesis Lintasan Belajar (HLB) yang lebih baik.

2. Penelitian ini merupakan program renedial, di mana peserta didik telah memiliki pemahaman awal mengenai pola bilangan sehingga implementasi MEAs untuk mengembangkan kemampuan penalaran induktif secara umum di saat KBM berlangsung belum diketahui.

\section{REFERENSI}

Burke, D., Jacobs, L. C., Sorensen, C., \& Razavieh, A. (2010). Educational Research: Quantitative, Qualitative, and Mixed Approaches ( $8^{\text {th }}$ edition). Wadsworth: Cengage Learning.

Chamberlin, S. A. (2002). Analysis of interest during and after model eliciting activities: a comparison of gifted and general population students (Doctoral Dissertation). Tersedia dari ProQuest Dissertations and Theses database. (UMI No. 3099758)

Chamberlin, S. A. \& Moon, S. M. (2005). Model-eliciting activities as a tool to develop and identify creatively gifted mathematicians. The Journal of Secondary Gifted Education. 17(1): 37-47.

Gravemeijer, K. (2004). Local instruction theories as means of support for teachers in reform mathematics education. Mathematical Thinking and Learning. 6(2): 105-128.

Gravemeijer, K. \& van Eerde, D. (2009). Design research as a means for building a knowledge base for teachers and teaching in mathematics education. The Elementary School Journal. 109(5): 510-524.

Kementerian Pendidikan dan Kebudayaan. (2017). Buku Guru Matematika Kelas VIII SMP/MTs. Edisi Revisi. Jakarta: Pengarang.

Lake, Jo-Anne. (2009). Memories You Can Count On: A Literature-Based Approach to Teaching Mathematics in the Primary Classrooms. Canada: Pembroke Publishers.

Lesh, R. A., Hoover, M., Hole, B., Kelly, A. E., \& Post, T. (2000). Principles for Developing ThoughtRevealing Activities for Students and Teachers. Dalam A. E. Kelly \& R. A. Lesh (Eds.), Handbook of Research Design in Mathematics and Science Education (pp. 591-645). Mahwah, N.J.: Lawrence Erlbaum Associates.

Maulana. (2017). Konsep Dasar Matematika dan Pengembangan Kemampuan Berpikir Kritis-Kreatif. Sumedang: UPI Sumedang Press.

Patterns. (n.d.). Diperoleh pada May 27, 2019 dari http://aamt.edu.au/Topdrawer/Patterns

Prahmana, R., C., I. (2017). Design Research (Teori dan Implementasinya: Suatu Pengantar). Depok: PT RajaGrafindo Persada.

Sumarmo, U. (2017). Pemahaman, penalaran matematik, dan tahap kognitif siswa SMA revisi 2019. Diperoleh pada 18 Juni 2019 dari http://dosen.ikipsiliwangi.ac.id/utari-sumarmo/pemahamanpenalaran-matematik-dan-tahap-kognitif-siswa-sma-revisi-2019/

Taylor-Cox, J. (2005). Family Math Night: Math Standards in Action. New York: Routledge.

Wildani, J. (2018). Analisis kesalahan siswa dalam menyelesaikan masalah aljabar. Unisda Journal of Mathematics and Computer Science. 4(1): 9-18. 